\title{
The Controlling Factors of CBM Accumulation and Favorable Exploration areas in Eastern Junggar Basin, Xinjiang
}

\author{
Wang Lei, 2, a ${ }^{\text {* }}$ Tang Dazhen ${ }^{1,2}$, Li Jingjing ${ }^{3}$, Yu Tingxu ${ }^{1,2}$, Zhu Wuquan ${ }^{1,2}$, \\ Ren Pengfei ${ }^{1,2}$
}

\begin{abstract}
${ }^{1}$ School of Energy Resources, Key Laboratory of Marine Reservoir Evolution and Hydrocarbon Accumulation Mechanism, Ministry of Education; China University of Geosciences (Beijing), Beijing 100083, China
\end{abstract}

${ }^{2}$ School of Energy Resources, Key Laboratory of Shale Gas Exploration and Evaluation, Ministry of Land and Resoueces, China University of Geosciences (Beijing), Beijing 100083, China

${ }^{3}$ CNOOC Energy Technology \& Services-Engineering Technology Co. Tianjin 300457, China

awanglei_1011314@126.com

Keywords: Eastern of Junggar basin, CBM, Controlling factors of CBM accumulation, Depth of weathered zone of methane, Coal rank

\begin{abstract}
The information of coal-bed distribution, rank and gas-bearing nature of Jurassic coals in eastern Junggar basin were analyzed, and the controlling factors of coal-bed methane (CBM) accumulation were pointed out, which were coal rank, coal seam depth, and preservation conditions. The most important factor was depth of weathered zone of methane and coal rank. Consequently, Badaowan formation in Bogeda piedmont and Jimusaer depression and coal bed of Xishanyao formation in Wutongwozi depression were identified as the enriched areas of CBM in eastern Junggar basin. In a word, the Bogeda piedmont would be the main target for exploration in this area.
\end{abstract}

\section{Introduction}

Junggar basin is located in northern Xinjiang Uygur Autonomous Region. Closed to Carlamaili Mountain in north, in the south is Bogda Mountain. Junggar basinhas13 secondary tectonic units, such as shishugou depression, shiqiantan depression, wutongwozi depression and shaqi projections, et al. The Badaowan and Xishanyao formations containscoal seams, there are lots of coal mines in production. Coal stratas widely develop. Decades years ago, a successions exploration of coalbed gas were carried out in study area, such as the fumei 1 drilling in dahuangshan area at Bogeda piedmont, which had good production, the output of CBM from the wells achieved $1000 \mathrm{~m}^{3} / \mathrm{d}[1,2]$.

\section{The Distribution and Properties of Coal}

Coal Seam Distribution. The main coal-bearing stratas are interbedded in the Lower Jurassic Badaowan $\left(\mathrm{J}_{1} b\right)$ and the Middle Jurassic Xishanyao formations $\left(\mathrm{J}_{2} x\right)$. The coal strata mainly distributes in the secondary tectonic zone, such as Bogeda piedmont, Dajing, Wutongwozi, Jimusaer. In Shazhang and Dajing area the thickness of main coal is $10-15 \mathrm{~m}$ at macro distribution, and lateral stability with shallow buried. Wutongwozi and Jimusaer depression have several main coal seams, the thickness for which is more than $30 \mathrm{~m}$ [3].

The coal-bearing strata in Badaowan formation has good development at Bogeda piedmont, the thickness of which reaches 5-10 m, usually developes 1-2 seams, but the depth of coal seams always is less than $900 \mathrm{~m}$. The xishanyao coal-bearing strata deposites at north of this study area, the thickness of which is more than $40 \mathrm{~m}$ totally, however, the thickness changes drastically in the transverse direction.

Coal Characterization. Based on the latest information, the macro-distribution, coal rank, coal quality and gas-bearing nature of Jurassic coals in eastern Junggar basin are analyzed comprehensively. The main controlling factors of coal-bed methane accumulation in this area are 
clarified as coal-bed burial depth, coal rank, coal quality and preservation condition, and the most important ones are the depth of weathered zone of methane and coal rank. Consequently, the enriched areas and horizons of coal-bed methane in eastern Junggar basin are identified, namely Bogeda piedmont, Badaowan formation in Jimusaer sag and coal bed of Xishanyao formation in Wutongwozi sag. Considering the factor of depth, the Bogeda piedmont will be the main target for exploration in this area in the future [4].

Table 1. Vitrinite reflectance and gas analysis data of Jurassic coal in Zhundong.

\begin{tabular}{|c|c|c|c|c|c|c|c|c|}
\hline Wells or mines & $\begin{array}{c}\text { sampling } \\
\text { depth }\end{array}$ & Formation & $\begin{array}{l}\text { Thickness } \\
/ \mathrm{m}\end{array}$ & $\begin{array}{l}\text { Reflectance } \\
\text { of vitrinite }\end{array}$ & $\begin{array}{l}\text { measured } \\
\text { gas content }\end{array}$ & $\begin{array}{l}\text { Vitrinite } \\
\text { content/\% }\end{array}$ & $\begin{array}{c}\text { Volatile } \\
1 \%\end{array}$ & $\begin{array}{c}\text { ash } \\
\text { yield/\% }\end{array}$ \\
\hline \multirow{2}{*}{ Zhangpenggou } & 323 & $\mathrm{~J}_{1} x$ & & 0.41 & 0.09 & 46.1 & 36.1 & 5.8 \\
\hline & 565 & $\mathrm{~J}_{1} x$ & & 0.44 & 0.227 & 61.3 & 38.7 & 4.0 \\
\hline \multirow{2}{*}{ Beishan } & 153.91 & $\mathrm{~J}_{1} x$ & \multirow{2}{*}{$25-32$} & 0.42 & 0.091 & 56.3 & 32.7 & 14.3 \\
\hline & 170.48 & $\mathrm{~J}_{1} x$ & & 0.47 & 0.195 & 51.7 & 34.5 & 21.8 \\
\hline \multirow{2}{*}{ Fumei 1} & $\begin{array}{l}703.97- \\
704.40\end{array}$ & $\mathrm{~J}_{1} b$ & \multirow{2}{*}{$10-35$} & 0.68 & 10.71 & 52.7 & 45.5 & 30.1 \\
\hline & $\begin{array}{c}709.27- \\
709.58 \\
\end{array}$ & $\mathrm{~J}_{1} b$ & & 0.69 & 11.06 & 69.3 & 30.3 & 35.5 \\
\hline \multirow{2}{*}{ Fucan 1} & I & $\mathrm{J}_{1} b$ & & 1 & 7.92 & 46.2 & 36.9 & 16.4 \\
\hline & I & $\mathrm{J}_{1} b$ & & I & 14.28 & 57.8 & 30.2 & 17.9 \\
\hline \multirow{2}{*}{ Shamei 1} & $\begin{array}{c}\text { 703.97- } \\
704.4 \\
\end{array}$ & $\mathrm{~J}_{1} x$ & \multirow{2}{*}{$10-15$} & 0.77 & 0.167 & 61.9 & 31.5 & 13.1 \\
\hline & $\begin{array}{l}787.64- \\
787.93\end{array}$ & $\mathrm{~J}_{1} x$ & & 0.65 & 0.036 & 63.1 & 37.2 & 9.8 \\
\hline
\end{tabular}

\section{The Gas Bearing Characteristics}

Coal types are mainly consisted of lignite and long flame coal. The capacity of producingthermogenic gas is low. And the gas content of coal seam is not high, but the gas content changes from one place to another in eastern of Junggar basin. Gas bearing is $10.9 \mathrm{~m}^{3} /$ tin Fumei 1 at Badaowan formation in Dahuangshan area, fucan 1 well is $14.28 \mathrm{~m}^{3} / \mathrm{t}$, which is the best wells in Zhundong coalfield [2]. The gas content is less than $0.2 \mathrm{~m}^{3} / \mathrm{t}$ inXishanyao formation at Shazhang area. In Dajing and Wutongwozi depression the coal strata of Xishanyao haslow gas content (0.01 0.27 $\mathrm{m}^{3} / \mathrm{t}$ ). Gas logging show Badaowan coal has good gas bearing in Jimusaer depression, but the coal seams are buried deeper than $1000 \mathrm{~m}$.

The porosity ranges from $0.4 \%$ to $16.4 \%$, permeability rate there changes from $0.22 \mathrm{mD}$ to $165.3 \mathrm{mD}$, average $64.3 \mathrm{mD}[5]$.

Totally, the worst gas bearing is Dahuangshang with Badaowan formation, followed by Jimusaer depression [6].

\section{Main Control Factors of Gas Bearing}

Coal Rank and Maceral. The Coal in Dahuangshan and Shazhang area have higher maturity than other areas, which mainly includeslong flame coal and gas coal, both of whichhave great difference in the gas content. The Dajing and Beishan coal have lower maturity, and the gas content is very low. It is very clear that where the coal has higher maturity the gas bearing is better. Badaowan formation hasgood coal quality than Xishanyao, therefore the gas bearing is better than Xinshanyao coal seams. Thegas bearingof Bogeda piedmont is better than the other area of zhungdong coalfield. Badaowan coal is characterized by semi-bright and bright coal.

When it comes to low rank coal, thermogenic-gas and bio-gas are the two major gas sources. Each secondary structure unit was cutted by deep faults in eastern of Junggar basin upwelling area, and there is no smooth migration channels between each secondary structure unit, therefore there is no more thermogenic gas migration from other secondary structure units around them. Coal bed methane 
in most parts of eastern of Junggar basin has poor formation condition for biological source [7], and the composition and content of coal bed methane illustrate this point. At the piedmont area coal bed methane obviously is supplemented by biological gas, most of the methane carbon isotope is less than $-55 \%$. The $97.6 \%$ of coal bed natural gas is methane, the carbon isotope of that is $-55.96 \%$, ethane carbon isotope of $-27.60 \%$ in fumei 1 well [2]. That shows the gas is composited with bio-gas.

The Buried Depth of Coal. The desorption datas of coalbed methane show that little methane existes when the depth is below $250 \mathrm{~m}$, and the composite of methane increasesby depth in Dajing and Wutongwozi depressioninnorth of Zhundong coalfield, and the main composite of coal bed nature gas is nitrogen and carbon dioxide (more than $90 \%$ ). The beishan mine is located at wutongwozi depression, which has low gascontent (less than $0.10 \mathrm{~m}^{3} / \mathrm{t}$ ), and is mainlycomposited by nitrogen and carbon dioxide. But thegas logging data of Fumei 1 wells of shows piedmont area hasgood gas bearing below $400 \mathrm{~m}$, thecoal containsgas more than $10 \mathrm{~m}^{3} / \mathrm{t}$ at $710 \mathrm{~m}$. Also in those areas the mine methane dates show high coal bed methane content. Hydrocarbon exploratory well of Junggar basin shows coal bed methane content increases with depth, which reflects that the regularity is consistent with measured datas. Based on the existing data speculation, the depth of methane weathered zone is generally 800 900 m, average $850 \mathrm{~m}$ in Zhundong area [4], the Bogda Piedmont area is about $400 \mathrm{~m}$. the depth of methane weathering zone controlles the gas contend severely. By Contrasting the methane weathering zone of the study area with the Powder River basin (PRB) and the Junggar basins, we find that it is much deeperthan that in PRB. It results from the different hydrological conditions.

Generally speaking, the formation is weak aquifer in zhundong coalfield, of which chemical types of groundwater is $\mathrm{SO} 4 \cdot \mathrm{Cl}-\mathrm{Na}, \mathrm{Cl}-\mathrm{Na}$, the degree of mineralization is $875.4-16326.9 \mathrm{mg} / \mathrm{L}$. Coalbed methane (CBM) resources in the Junggar Basin, Xinjiang, China are abundant. The most favorable targets for CBM resources occur in the southern Junggar Basin, with stable and thick coal seams, shallow buried depth and higher CBM content. The lack of geological knowledge of CBM accumulation and generation is the reason why the exploration in the region had not achieved for many years. Based on the analysis of CBM accumulating conditions, it was considered that the favorable geological controls of CBM accumulation occur in southern Junggar with the higher coal rank, the better hydrological conditions and the abundant gas supply including the secondary biogenic gas and pyrolzed deep gas. CBM content is low in eastern Junggar because of the lower coal rank, higher groundwater mineralization and the poor CBM preservation. On the basis of the analysis abovementioned, it was suggested that the key geological controls of CBM accumulation in the southern Junggar are the structure, hydrology and cap-rock. Favorable structural positions could control the pyrolyed deep gas supply. The hydrogeological conditions might be favorable of secondary biogenic gas generation. The favorable cap rocks could make CBM to be preserved.

The Preservation Conditions. Preservation conditions are referred to the structure damage, coal roof, footwall characteristics of lithology combination and its horizontal distribution. The important factors that have an important in CBM reservoir preservation are the subsidence and uplift, they would lead to the formation compressional and tensile deformation. After middle Jurassic Toutunhe formation deposition, Yanshan's medium-term movement made the area uplift, and the Jurassic Shishugou group suffered erosion. The Cretaceous and Jurassic are regional unconformity contacted, due to the depositions of long intermittent period. The erosion is about $600 \mathrm{~m}$ of Xishanyao Formation and the young strata, which suffered a long time of weathering damage. There is no regional stability mudstone caprock on the coal seams, preservation conditions are not good, which make gas content become lower [5]. It is fluviolacustrine sedimentary facies of Jurassic in Junggar basin, great changes exsit on coal lithology, the coal seam roof and floor lithology combination are complex. When roof and floor are mudstone, the content of coal bed rises. Gas logging datas reflect this phenomenon well. However, when the coal roof and floor are sandstone in Shaqiu 8 well in badaowan formation, gas content is very low without the occurrence of abnormal values, and the coal roof and floor are also mudstone in Tong 2 well, gas logging anomaly is very obvious. 


\section{Coalbed Methane Enrichment and Exploration Target}

According to above analyses, the coalbed methane enrichment regularities areas follows: (1) High rank coals with good quality have more obvious gas content than the Xishanyao Formation. (2) Methane weathered zone controls the gas content strictly, gas content increases asthe depth increases.

In order to predict the coalbed methane enrichment favorable zone in Zhundong Area, based on the previous investigation, in combination with the lithotype and coal quality and adsorption capacity test, a study was conducted on the gas bearing under the control of the coalbed methane enrichment factors, front area of Bogeda Mountain of Zhundong coalbed methane enrichment zone, Jimusaer Depression and Wutongwozi Depression. The front area of Bogeda Mountain was the first selected target zone. The results showed that the front area of Bogeda Mountain had good coalbed methane formation condition, the gas bearing was obvious, the buried depth was moderate, the seam layout condition was good and the accumulated thickness was high. The seam was medium and high volatile, low moisture content and low ash quality coal. The coal and rock adsorption capacity was high. The main control factors of the coalbed methane enrichment in Zhundong Area were that the lithotype and coal quality and air oxidized zone depth, coal and rock adsorption capacity and coal grade, vitrinite content would be in a positive correlation, would be in a negative correlation to the inertinite and moisture content and the fitting optimized was high. The features of the air oxidized zone distributed in Zhundong Area would be deep in north and shallow in south. The seam in the front area of Bogeda Mountain generally would be deeper than floor line of the air oxidized zone.

\section{Conclusion}

The exploration, development and resourcse distribution of coal-bed gas at home and abroad are analyzed and discussed in this paper,and the genedis of coal-bed gas, the occurrence characteristics and the factors of enrichment are studied. Based on this,combining with the geological distribution and evolutionary characteristic of middle-lower Jurassic coal bed in Jumggar basin, It is pointed out that Badaowan and Xishanyao formations are most developed in the south margin of the basin in the paper. Although the evolution is in the low-ranked coal stage, the gas content ratio is high. The simulation experiment of coal rock has also proved that the coal rock has a better gas generating potential. We use the successful experiences of developing low-ranked coal-bed gas in the U.S.A for reference to predict the favorable areas for forming coal-bed gas reservirs, and the result is that the Jurassic Xishanyao Formation is the most favorable zone, while the eastern part of south margin is the most favorable area for exploring coal.

\section{References}

[1] D. G. Liu, X. Z. Wu and Z. Y. Zhao, et al. The Potential and Prospect Areas of Coalbed Gas Resource in Junggar Basin. Xinjiang Petrol. Geol. 28(3) (2007) 272-274.

[2] D. G. Liu, X. J. Luo and M. Wan, et al. The Coal-Bed Mathane Accumulation Factors and Explorative Target in Eastern Junggar Basin. Xinjiang Petrol. Geol. 31(4) (2010) 349-351.

[3] Q. P. Sun, H. L. Liu and H. Y. Chao, et al. Exploration direction of coalbed methane in low-rank coals. Nat. Gas Ind. 28(3) (2008) 19-22.

[4] Q. P. Sun, B. Sun and F. J. Sun, et al. Accumulation and Geological Controls of Low-Rank Coalbed Methane in South eastern Junggar Basin. Geol. J. China U. 18(3) (2012) 460-464.

[5] Y. J. Wei, Preliminary Study on Low-rank Coal Reservoirs and Coalbed Methane Pool Forming in Zhungaer Basin, NW China. Beijng, China University of Geosciences Beijing, (2002).

[6] K. J. Tan, F. Zhang and Y. C. Zhao, et al. Exploration Potential And Favorable Target Prediction Of Jurassic Coal-Bed Gas In Junggar Basin. Nat. Gas Explor. Dev. 32(2) (2009) 1-3. 
[7] S. H. Cui, L. H. Lin and B. Wang, et al. Trapping Characteristics of Coalbed Methane in Low-rank Coal of Zhungaer Basin. Geosci. 21(4) (2007) 719-724. 